\title{
INTRATHORACIC KIDNEY IN A PREMATURE INFANT
}

\author{
BY
}

\author{
EMMANUEL SHAPIRA, EFRAIM FISHEL, and STANLEY LEVIN \\ From the Departments of Paediatrics and Radiology, Kaplan Hospital, Rehovoth, Israel
}

(RECEIVED FOR PUBLICATION JUNE 12, 1964)

Though ectopia of the kidney is a common anomaly (Campbell, 1951) displacement is usually downwards towards the pelvis, or medially. Upward displacement into the thoracic cavity is a much rarer finding. Ashley and Mostofi (1960), in a review of some quarter of a million necropsies, did not find a single case of thoracic kidney.

The present report is of interest because of the diagnosis of this condition in a living newborn premature baby.

\section{Case Report}

A premature infant, weighing $2,400 \mathrm{~g}$., was born to healthy parents following normal pregnancy and childbirth. There are two healthy sibs, but one previous premature infant died soon after birth.

At the age of 13 days, the infant was admitted to the paediatric department with an infection of the skin in the region of the sacrum. The weight at this time was $2,400 \mathrm{~g}$. Breathing was normal. The facies was somewhat peculiar (Fig. 1), with a narrow forehead, flattened base of nose, and with eyes set wide apart. The mouth was smallish, with a narrow high-arched palate. The ears were low set. There were flexion deformities of the 3rd, 4th, and 5th fingers of the left hand, and 4th and 5th fingers of the right hand, which prevented normal extension at the finger joints. The thumbs were somewhat abnormally positioned, and flexion and abduction were slightly limited. These latter features were unlike arthrogryposis, in that on flexing the wrist and relaxing tension of the flexor tendons, full extension of the fingers could be obtained. Difficulty was entertained in abducting the hips, but there was no other evidence of subluxation at the hip joints.

Dullness was noted over the left lower chest, and air entry was diminished in this area. There were no abnormal adventitious sounds.

Laboratory examinations of the blood including blood count, urea, sugar, calcium, phosphorus, alkaline phosphatase, G.O. transaminase, and electrophoresis of proteins were within normal limits. Several examinations of urine were normal, as well as examination for total urinary amino acid excretion, and amino acid chromatography. Urinary calcium and phosphorus excretion were normal.

Chest radiographs showed a homogeneous density of the lower third of the left thorax, with no displacement of the heart or mediastinum. Radiographs of the spine, sacrum, and pelvis showed no evidence of abnormalities. Because of the skin infection and the abnormal chest findings, the infant was treated with antibiotics as a suspected case of cellulitis with pneumonia.

The skin infection responded to this therapy, and the infants condition improved. At no time was there any respiratory distress. Repeat radiographs of the chest showed no change, though it was noted that the posterior medial aspect of the left diaphragm appeared abnormal. Barium swallow was performed because of the suspicion of a diaphragmatic hernia, but the digestive system was found to be normal.

Because of the congenital deformities of the limbs, together with the peculiar facies and low-set ears, an abnormally placed kidney was suspected as the cause of the pathology in the left chest.

Intravenous pyelography with multi-section tomography demonstrated an ectopic left kidney occupying the left lower chest. The calyces were normal and were

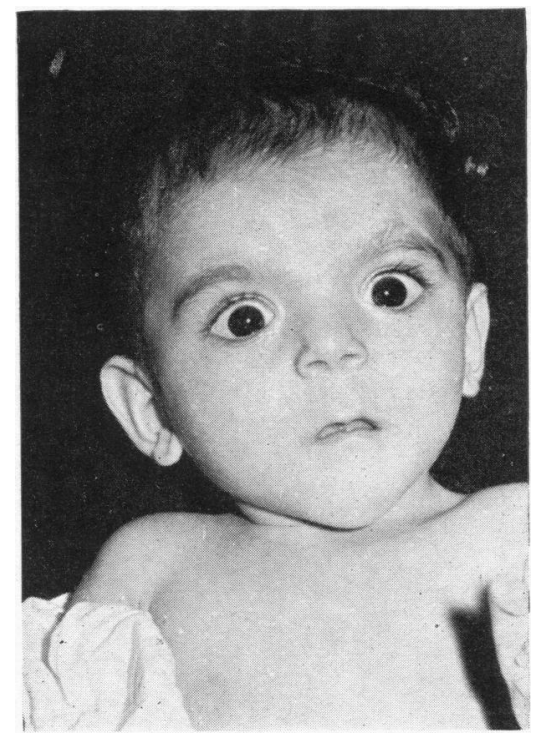

FIG. 1.-Wide-set eyes, small mouth, large low-set ears, and pointed chin in infant with intrathoracic kidney. 
noted to be above the diaphragm. The pelvis seemed a little dilated. The right kidney and the bladder were normal (Fig. 2).

In an attempt to delineate further the kidney, intravenous pyelogram was performed together with pneumoperitoneum and pre-sacral air insufflation. The liver and spleen were found in their normal positions. The left kidney was noted to be retroperitoneal with the greater proportion above the diaphragm.

At the age of 1 year the infant is well, but srrall, and has had several respiratory infections requiring admission to hospital. At this time bilateral subluxation of the temporo-mandibular joints was found.

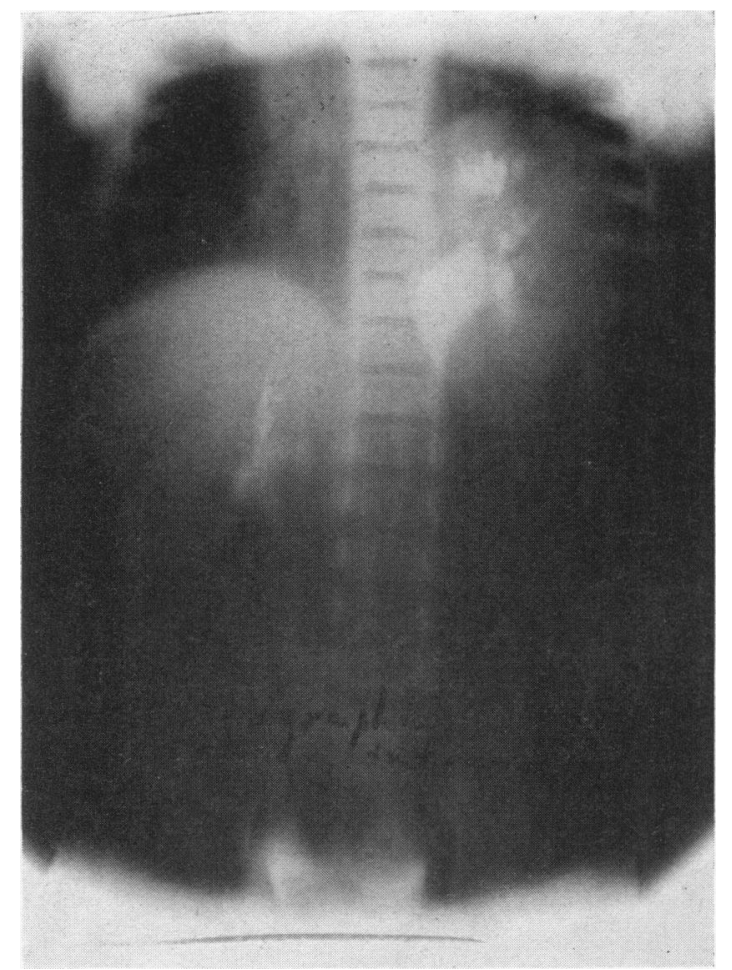

FIG. 2.-Intravenous pyelography with tomcgraphy showing left intrathoracic kidney.

\section{Discussion}

A review of the published material indicates that cases of thoracic kidney are rarely diagnosed clinically because of lack of symptoms, and that the present case is the youngest in which such diagnosis has been made. Thoracic kidney in foetuses and stillborns has been reported (Gruber, 1927), as well as at necropsy in young children (Campbell, 1951). In the majority of necropsy reports, multiple congenital deformities have been noted, and in many cases, various other viscera have been found displaced into the chest. The first case diagnosed clinically was reported by Wolfromm (1940) who described a 40-year-old woman who was found on retrograde pyelography to have a thoracic kidney. Three reports during 1949-50 (Williams and Tillinghast, 1949; Spillane and Prather, 1949; Fleischner, Robins, and Abrams, 1950) purported to describe the first clinically diagnosed cases. Schwartz and Fränkel (1952) described a 65-year-old women, in which a left homogeneous basal density was noted on a routine chest radiograph, and which was proved to be an ectopic left kidney. Robbins and Lich (1954) reported a further case and reviewed the literature available to him, and found 6 cases in which the diagnosis was made clinically, and 4 others that were found at necropsy.

The present review considers cases diagnosed during life, and includes the literature up till 1961 (Gondos, 1955; Bulgrin and Holmes, 1955; Barloon, Goodwin, and Vermooten, 1957; Berlin, Stein, and Poppel, 1957; Laumonier, Verger, Fréour, Nicol, and Delormas, 1957; Herrenschmidt and Daumet, 1957; Pescione, 1957; Witz, Reys, and Wagner, 1958; Reboud and Bernard, 1958; Veran, Moigneteau, and Auvigne, 1958; Röhrig, 1958; Frančišković and Martinčić, 1959; Bernard, Reboud, and Maestraggi, 1959; Hill and Bunts, 1960; Paul, Uragoda, and Jayewardene, 1960; Nini, 1961). A further 8 reports (Pini, Newkirk, and Casal, 1954; Sypniewska, 1955; Herink and Jagdschian, 1960; Hayashi, 1961; Manfredi, 1961; Daroczy, 1959; De Langlade and Pelizza, 1958; Toole, Chrysopathis, and Papadimitriou, 1961) were not available for review.

In all, 28 cases of thoracic kidney diagnosed clinically have been reported; 14 were left-sided, 13 were right-sided, and one (Berlin et al., 1957) was bilateral.

The greater proportion of them were discovered following investigation of abnormal basal densities in chest radiographs. Several cases were operated on because of the suspicion of lung neoplasm. The abnormality was found three times more often in males. The youngest reported case, until the present report, was in a child of 4 years of age, and the oldest in a 75-year-old person. The average age of reported cases was 41 years.

Embryologically, the explanation for the displacement of the kidney is not clear, and various possibilities have been suggested. Spillane and Prather (1952) and Barloon et al. (1957) felt that the cause of the abnormality was due to a maldevelopment of the pleuro-peritoneal membrane, causing the ascending process of the kidney to continue into the chest. 
Others believed the cause to be a delay in the caudal migration of the mesonephron, leading to a defect in the diaphragm which allowed the kidney to be displaced cranially. Gondos (1955), on the other hand, believed that delay in the joining of the ureteric bud to the metanephron led to late differentiation of metanephronic tissue, which in turn caused accentuation of the ascending process. Frančišković and Martinčić (1959) thought the cause was primarily a high cephalic establishment of the renal germ.

Clinically, thoracic ectopic kidney is asymptomatic, there being no hydrodynamic changes in the urinary outflow tract, and it therefore does not require specific therapy. The majority of cases are diagnosed incidentally to fluoroscopy of the chest. On the other hand, pelvic or abdominal ectopy may lead to recurrent urinary tract infections, stone formation, and hydronephrosis. These latter cases are usually diagnosed during investigation of the genito-urinary tract.

\section{Summary}

Ectopic displacement of the kidney into the left or right chest is a rare anomaly. A review of the literature revealed 28 cases in which this condition was diagnosed clinically. The great majority of cases were in adults and almost all were asymptomatic, and were diagnosed incidental to chest fluoroscopy. A case is reported of a left thoracic kidney diagnosed clinically in a premature newborn infant with peculiar facies, congenital abnormalities of the fingers, and subluxation of the temporo-mandibular joints.

\section{REFERENCES}

Ashley, D. J. B., and Mostofi, F. K. (1960). Renal agenesis and dysgenesis. J. Urol. (Baltimore), 83, 211.

Barloon, J. W., Goodwin, W. E., and Vermooten, V. (1957). Thoracic kidney: case reports. ibid., 78, 356.

Berlin, H. S., Stein, J., and Poppel, M., H. (1957). Congenital superior ectopia of the kidney. Amer. J. Roentgenol., 78, 508.

Bernard, R., Reboud, E., and Maestraggi, P. (1959). A propos d'une image en coucher de soleil de l'hémi-coupole diaphragmatique droite (ectopie rénale intra-thoracique). Pédiatrie, 14, 293.

Bulgrin, J. G., and Holmes, F. H. (1955). Eventration of the diaphragm with high renal ectopia. Radiology, 64, 249.

Campbell, M. (1951). Clinical Pediatric Urology, p. 195. Saunders, Philadelphia.

Daroczy, G. (1959). Intrathoracic kidney dystopia. Magy. Sebész., 9, 201.

De Langlade, E., and Pelizza, A. (1958). Su di un raro caso di ectopia toracica del rene destro. (An unusual case of thoracic eccopia of the right kidney.) Minerva pediat., 10,981.

Fleischner, F. G., Robins, S. A., and Abrams, M. (1950). High renal ectopy and congenital diaphragmatic hernia. Radiology, 55, 24.
Frančiškovič, V., and Martinčič, N. (1959). Intrathoracic kidney. Brit. J. Urol., 31, 156.

Gondos, B. (1955). High ectopy of the left kidney. Amer. J. Roentgenol., 74, 295.

Gruber, G. B. (1927). Die Missbildungen des Zwerchfells. In Die Morphologie der Missbildungen des Menschen und der Tiere, ed. E. Schwalbe and G. B. Gruber, Part JII, Div. 3, Chapter 2. Fischer, Jena.

Hayashi, Y. (1961). Thoracic kidney. A case report. Jap. J. Urol., $52,676$.

Herink, M., and Jagdschian, V. (1960). Klinischer Beitrag zur partiellen rechtsseitigen $Z$ werchfellrelaxation mit dystoper Niere in der rechten Thoraxhöhle. Thoraxchirurgie, 8, 463.

Herrenschmidt, M. M., and Daumet, P. (1957). Diagnostic radiologique d'un rein en ectopie thoracique. Poumon, 13, 817.

Hill, J. E., and Bunts, R. C. (1960). Thoracic kidney: case reports. J. Urol. (Baltimore), 84, 460.

Laumonier, Verger, Fréour, Nicol, and Delormas (1957). Ectopie thoracique du rein droit. Poumon, 13, 119.

Manfredi, L. (1961). On a case of Bochdalek's hernia in the adult with thoracic ectopy of the right kidney. Acta chir. ital., 17, 223.

Nini, W. (1961). Le rein intrathoracique. Bull. Soc. int. Chir., 20, 548.

Paul, A. T. S., Uragoda, C. G., and Jayewardene, F. L. W. (1960). Thoracic kidney with report of a case. Brit. J. Surg., 47, 395.

Pescione, E. (1957). High renal ectopy $-A$ contribution to the knowledge of the so called 'thoracic kidney'. Urol. int. (Basel), $4,142$.

Pini, A. E., Newkirk, G., and Casal, J. (1954). Ectopía renal torácica. Rev. argent. Urol., 23, 111.

Reboud, E., and Bernard, R. (1958). Un nouveau cas d'ectopie rénale intrathoracique. Poumon, 14, 597.

Robbins, J. J., and Lich, R., Jr. (1954). Thoracic kidney. J. Urol. (Baltimore), 72, 133.

Röhrig, H. (1958). Kongenitale thorakale Ektopie der rechten Niere. Fortschr. Röntgenstr., 89, 371.

Schwartz, A., and Fränkel, M. (1952). High renal ectopia, detected on routine chest examination : case report. Acta radiol. (Stockh.), 37, 583.

Spillane, R. J., and Prather, G. C. (1949). High renal ectopy: a case report. J. Urol. (Baltimore), 62, 441.

_. - (1952). Right diaphragmatic eventration with renal displacement: case report. ibid., 68, 804.

Sypniewska, M. (1955). Wrodzone wysokie polozenie ncrki. Pol. Przegl. chir., 27, 467.

Toole, H.. Chrysopathis, P., and Papadimitriou, D. (1961). Uber die thorakale Nierendystopie Mitteilung eines neuen Falles. $Z$. Urol., 54, 1.

Veran, P., Moigneteau, C. R., and Auvigne, J. (1958). Opacité de la base droite par malformation rénale. Poumon, 14, 763.

Williams, R. G., and Tillinghast, A. J. (1949). Diaphragmatic herniation of kidney: case report. Radiology, 53, 566.

Witz, J. P., Reys, P., and Wagner, J. P. (1958). Ectopie thoracique partielle du rein gauche. Poumon 14,595.

Wolfromm, G. (1940). Situation du rein dans l'éventration diaphragmatique droite. Méd. Acad. Chir., 66, 41 .

\section{Addendum}

After submitting this report, chromosome analysis was performed on leucocytes of this child by Dr. B. Pade, of the Chromosome Laboratories, Tel Hashomer Hospital, Tel Aviv. These studies showed a trisomy 16-18 pattern with translocation of one of the 6-12 X chromosomes to No. 2 chromosome, which was occasionally of giant size.

Details of these findings, including family studies, will be the subject of an additional report. 